\title{
THE ROLE OF INTELLIGENCE
}

\section{AND TEMPERAMENTAL TRAITS}

IN PREDICTING REACTION TIMES

IN MOVEMENT ANTICIPATION TASKS:

A PRELIMINARY STUDY USING

\section{THE PAMT TEST2DRIVE COMPUTER TEST}

\author{
Monika Maria Małkiewicz \\ Cardinal Stefan Wyszyński University in Warsaw, Warsaw, Poland \\ Institute of Psychology
}

\begin{abstract}
Background: The objective of the present work was to determine whether fluid intelligence scores and individual temperamental traits may be used to predict drivers' reaction times in movement anticipation tasks. Material and Methods: The study encompassed 68 young female drivers (aged 20-26 years), who had received their driver's licenses at least 2 years prior. Anticipatory performance was evaluated using the Perception Anticipation Movement Test (PAMT) consisting of 3 sets of computer tasks differing in the speed of the moving objects. The level of fluid intelligence was determined using Raven's Standard Progressive Matrices, and the temperamental traits with the Pavlovian Temperament Survey. Results: Intelligence was found to be significantly correlated with reaction time only in the second PAMT task set, for which it was also a good predictor. Findings suggested that a higher level of fluid intelligence in young female drivers was associated with longer reaction times in the movement anticipation task with objects moving at the medium speed level. Temperamental traits did not correlate with reaction times in all movement anticipation tasks, and they did not explain the participants' performance in the PAMT task sets. Conclusions: This study expands the current literature by assessing the relationship between fluid intelligence, temperamental traits and reaction times in movement anticipation tasks with objects moving at different speeds. The outcomes of this study are discussed together with those of previous research. Med Pr. 2020; 71(4):421-7
\end{abstract}

Key words: reaction time, intelligence, temperamental traits, anticipation, movement anticipation, female drivers

Corresponding author: Monika Maria Małkiewicz, Cardinal Stefan Wyszyński University in Warsaw, Institute of Psychology, Wóycickiego 1/3 bud. 14, 01-938 Warsaw, Poland, e-mail: m.malkiewicz@uksw.edu.pl

Received: October 14, 2019, accepted: March 2, 2020

\section{INTRODUCTION}

In transportation psychology, anticipation is understood as the ability to predict successive upcoming traffic events and is thought to involve a directed perception of objects, an appraisal of their distance and speed, and an understanding of the principles behind their motion. An accurate determination of spatiotemporal relations between traffic objects is one of the key elements of situation awareness [1], which is critical for the safe behavior of drivers on the road [2].

The anticipation ability consists of perception processes, attention, and intellectual processes. Involvement in road incidents (causing or avoiding them) depends on the speed of traffic analysis, processing, and prediction by drivers, which depends, among others, on their general intelligence, or capacity to reason [3], and temperamental traits [4].

The objective of the present work was to elucidate whether general (fluid) intelligence and temperamental traits may serve as reaction time predictors in appraising the direction and speed of moving objects, using the Perception Anticipation Movement Test (PAMT) developed by Test2Drive (T2D) [5], which purports to recreate conditions similar to those found in real-life vehicular traffic. In particular, this study analyzes the predic-

Funding: this study was supported by Cardinal Stefan Wyszyński University in Warsaw (grant for statutory research No. UmoBMF-3/17, entitled "Temperament as a moderator of the relationship between cognitive abilities and sensorimotor skills of drivers," grant manager: Monika Małkiewicz, Ph.D.). 
tive value of fluid intelligence and temperamental traits in relation to reaction times recorded under 3 PAMT experimental conditions differing in terms of the speed of the computer marker (in 3 successive sets of tasks), as well as in relation to the overall PAMT performance.

\section{Effects of intelligence}

\section{and temperament on driver behavior}

The functional role of intelligence and temperament has been extensively studied, also in the field of transportation psychology $[3,4,6]$. Terelak [2] noted that a reliable verification of driver behavior models should involve the individual ability to process data and react in complex situations, which is modified, among others, by one's intelligence and temperamental traits.

Generally speaking, intelligence determines the performance of tasks requiring the use of various cognitive processes, including "reasoning, planning, problem-solving, abstract thinking, comprehension of complex ideas, fast learning, and drawing on one's experience" [7]. Among the many definitions of intelligence, this work focuses on 2 approaches, i.e., Spearman's [8] and Cattell's [9], which have gained currency in transportation psychology. In Spearman's 2-factor model, general intelligence $(\mathrm{g})$ is strongly associated with performance on intellectual tasks, while the specific factor (s) is responsible for an individual's specific intellectual abilities, and for his or her performance on tasks that reflect them. In turn, Cattell [9] subdivided general intelligence into fluid (Gf), grounded in biology and independent of acculturation, and crystallized intelligence (Gc), associated with the specific experience, knowledge, and acquired skills of the individual. Both approaches point to intelligence-based individual differences in terms of the speed and efficiency of information processing. They also agree as to the physiological underpinnings of general/fluid intelligence.

Interestingly, throughout the 20th century, there was some confusion in the field of intelligence research about the abilities that should be considered as the content of Spearman's $g$. However, the issue has been solved thanks to the research on Cattell's theory. It turned out that the reasoning factor that relates closely to Cattell's Gf, might also exemplify Spearman's g [7]. The reasoning abilities are the key factors measured in Raven's Standard Progressive Matrices test [10].

A substantial body of research [3,11-17] indicates the existence of a relationship between higher fluid intelligence levels and shorter reaction times (both in simple and decision reaction tasks), showing that individuals with higher Gf need less time to arrive at desired solutions. Jensen [11] noted that persons exhibiting higher intelligence not only react faster, but their response patterns are also more regular (with a lower variance of outcomes). Such persons make fewer errors and need fewer attempts to complete psychomotor tasks. Interestingly, in a subsequent study Jensen [12] found weak correlations between intelligence levels and reaction times in simple reaction tasks. This finding was attributed to the fact that such reactions are triggered by stimulus detection rather than derived from decision making processes, in contrast to the more complex choice reaction tasks (in which the correlation between Gf and the reaction time is much stronger). Similar results have been reported by other researchers $[18,19]$.

Other studies $[3,20]$ have pointed to a link between fluid intelligence and the speed and accuracy of eyehand coordination tasks. Truszczyński et al. [3] also found a significant relationship between Gf and a faster and more accurate visual tracking in a test requiring directed visual perception. In contrast to the above, Czeschlik [21] reported a negative correlation between fluid intelligence and reaction time, which was explained by the stronger reflectivity of individuals scoring higher on Gf. Still others [22] have claimed that the results of existing research have been affected by small sample sizes.

Research on temperament $[4,23]$ has indicated that it is significantly associated with driver behavior on the road. According to Strelau [24,25], temperament, which is directly linked to the properties of the human nervous system, fulfills a regulatory function by modifying (moderating) the stimulatory (energetic) and temporal value of reactions, and the value of the situations in which the individual finds him or herself [25]. In other words, temperament affects the intensity (strength) and temporal parameters (mobility and speed) of human reactions.

Similarly to Pavlov, Strelau enumerated the following temperamental characteristics: strength of excitation (SE), strength of inhibition (SI), and mobility of nervous processes (M) [26]. The first trait reflects one's readiness to engage in, or refrain from, activity in strongly stimulating situations, e.g., in the presence of a threat. High SE levels predict a better ability to work under highly stimulating conditions and to maintain task performance efficiency over time. High SE is also associated with a preference for risk-taking, greater resistance to fatigue, and responding with emotional reactions that are more appropriate to the situational requirements [25]. In turn, 
SI facilitates restraining task performance as well as delaying responses and interrupting activity if necessary. It also makes it easier not to reveal one's emotions if need be [25]. Finally, $\mathrm{M}$ enables adequate responses to changes, rapid adaptation to new conditions, and a readiness to switch between activities or to perform several tasks at a time [25].

In light of Strelau's approach, temperament may be expected to be also associated with reaction times in situations requiring object movement anticipation. While Strelau himself [27] did not find a conclusive relationship between temperamental traits and reaction times, some scholars [28] reported a correlation between SE and reaction times to stimuli of varying intensity. In addition, they found a negative correlation of SE and SI with anxiety and neuroticism, and a positive correlation of $\mathrm{M}$ with extraversion and Zuckerman's sensation seeking. Finally, according to Pascalis et al. [29], the high levels of sensory sensitivity associated with SE are also predictive of shorter reaction times.

Despite the fact that differences in reaction times arising from temperamental factors are associated with differences in the processing of cognitive information, the relationship between temperament itself and intelligence is inconclusive [30,31]. While some studies [30,31] have shown that fluid intelligence is correlated with temperament weakly and only in some age groups, other reports [32] do not corroborate any such correlations. In fact, little scholarly attention has been given to the effects of both intelligence and temperament (especially as defined with reference to the properties of the nervous system) on reaction times. Therefore, further investigation into the relationship between these variables seems necessary, and especially in the context of movement anticipation.

Last but not least, it should be noted that the majority of transportation psychology research has been conducted on professional male drivers, and there is a scarcity of reports on the behavior of female drivers. Moreover, few studies have examined ordinary car drivers. According to police records [33], most vehicular accidents are caused by non-professional drivers, but there are no data concerning their psychomotor abilities. Moreover, an increasing number of accidents are caused by the growing population of female drivers (albeit not as many as are caused by males).

\section{Research problem and hypotheses}

The main objective of this work was to identify temperament- and intelligence-related predictors of reaction times in dynamic situations requiring movement anticipation, in a group of young female drivers. The following research questions were formulated:

1. Are reaction times in movement anticipation tasks correlated with intelligence (reasoning) or temperamental traits?

2. What predictors could be useful in estimating reaction times in movement anticipation tasks? Can the same predictors be used to estimate reaction times in situations differing in terms of the speed of the moving objects?

In relation to the above questions, the following hypotheses were made:

H1: intelligence is negatively correlated with reaction times in movement anticipation tasks. Thus, the higher the intelligence level, the shorter the reaction time in dynamic situations requiring an appraisal of spatiotemporal relations between moving objects. The hypothesis is assumed to hold true irrespective of the speed of objects, i.e., for each of the 3 PAMT task sets and for the overall PAMT performance.

$\mathrm{H} 2$ : temperamental traits are associated with reaction times in situations requiring movement anticipation as follows: SE and M are negatively correlated with reaction times in anticipation tasks, while SI is positively correlated with that variable. Thus, the higher the SE and $\mathrm{M}$, the shorter the reaction time, while the higher the SI, the longer the reaction time. The hypothesis is assumed to hold true for each of the 3 PAMT task sets and for the overall PAMT performance.

H3: both intelligence and temperamental traits are good predictors of reaction times in dynamic situations requiring movement anticipation in each PAMT task set and in the overall PAMT performance.

\section{MATERIAL AND METHODS}

\section{Study group}

The study encompassed 68 females aged 20-26 years $(\mathrm{M}=21.66)$, who had received their driver's licenses at least 2 years prior to the study. None of the participants was a professional driver and all of them were right-handed. All were recruited for the study when taking a course in the psychology of stress, and were awarded additional academic credits for their participation. The final statistical analysis was conducted on 62 sets of test results obtained from the study group described above. 


\section{Procedure and methods}

All tests were administered individually at the Transport Psychology Laboratory, which is part of the Inter-Institute Central Psychological Laboratory of the Cardinal Stefan Wyszyński University in Warsaw. Each session lasted approx. $1 \mathrm{~h}$ and $30 \mathrm{~min}$. The participants first completed the paper-and-pencil questionnaires, and then took the computer tests. The methods are presented below.

Raven's Standard Progressive Matrices classic version (SPM-C) in paper-and-pencil format, in the Polish adaptation by Jaworowska and Szustrowa [10], was used to assess fluid intelligence. The test is consistent with Spearman's concept of intelligence [10]. It measures one's educative ability responsible for gaining new insights, making sense of chaos, as well as for going beyond the available information and the creation of new conceptions. It measures non-verbal abilities which are independent of experience, and which facilitate effective thinking. The SPM-C test consists of 60 items presented in 5 series (series A-E) of 12 items each. Each item in a given series consists of an incomplete pattern (matrix) and the participant's task is to determine which bit best completes the missing cell of the matrix. In the current study, the SPM-C test was given without a strict time limit, in paper-and-pencil format. The tool is characterized by high internal consistency and test-retest reliability [10].

The Pavlovian Temperament Survey (PTS) by Strelau and Zawadzki [26] was used to measure 3 temperamental traits: SE, SI, and M. These traits draw on the properties of the central nervous system as defined by Pavlov. The PTS is a paper-and-pencil questionnaire that consists of 57 statements in which respondents decide whether they agree or disagree with each of them, on a 1 ("definitely agree") to 4 ("definitely disagree") Li-kert scale. The PTS exhibits good psychometric properties [26].

The PAMT which is part of the T2D battery [5] was used to measure movement anticipation in dynamic situations. The T2D system is a standardized tool produced by Alta sp. z o.o. All tests in this battery are displayed on the Iiyama Pro Lite T2435MSC Full HD touch screen, which is provided by Alta sp. z o.o. to ensure standard conditions for all research using T2D. In the PAMT, the participants are required to guide a marker between 2 moving objects. The test is divided into 3 parts differing in marker speed (which successively decreases). The measurement trials are preceded by a training trial, in which the marker speed corresponds to the initial (fastest) test speed. Each part of the PAMT consists of a set of 6 tasks with an overall completion time of approx. $6 \mathrm{~min}$ [5]. Notably, the psychometric properties of the PAMT are still updated by the authors of the scale. The reliability obtained by the Spearman-Brown splithalf method $(r=0.843)$ and Cronbach's $\alpha(\alpha=0.775)$ showed acceptable coefficients. However, due to the fact that the PAMT is a relatively new test, its diagnostic validity has only been partially confirmed. Nonetheless, the authors consider the PAMT to be good enough for use in psychological practice [5, p. 118-21].

\section{Analysis of results}

Relationships between the variables were assessed using Pearson's $r$ correlations [34]. In turn, a hierarchical regression analysis was applied to predict reaction times in movement anticipation tasks $\left(\mathrm{RT}_{\mathrm{MAT}}\right.$ ) based on fluid intelligence and temperamental traits. In the first step, the regression equation contained general fluid intelligence scores, while the second step incorporated the 3 temperamental traits. Analyses were conducted for the 3 PAMT task sets and for the overall PAMT performance.

It should be noted that prior to the analyses, which were conducted for median reaction times, the data were standardized, outliers significantly affecting the regression plots were rejected, and the common logarithm was applied $[35,36]$. In addition, as 2 of the temperamental traits (SE and M) were found to be collinear, an analysis of semi-partial correlations was planned to be done to verify the results of the regression analysis.

\section{RESULTS}

Results for the relationships between variables posited in hypothesis 1 are given in Table 1. It was found that fluid intelligence levels were positively correlated with reaction times in movement anticipation tasks only in the second PAMT task set, which featured a medium speed of the computer marker.

Results for the relationships between temperamental traits and $\mathrm{RT}_{\text {MAT }}$ (hypothesis 2) are also included in Table 1. The findings indicate no significant correlations between all of these variables and the overall performance on the PAMT.

The results of multivariate regression analysis verifying hypothesis 3 are presented in Table 2. In the case of the overall PAMT performance, the first and the third PAMT set, the composite model including all predictors did not explain $\mathrm{RT}_{\text {MAT }}$ well. 
Table 1. Correlation coefficients of fluid intelligence scores and temperamental traits with reaction times in movement anticipation tasks (RTMAT) for the 3 PAMT task sets and the overall PAMT performance ${ }^{a}$

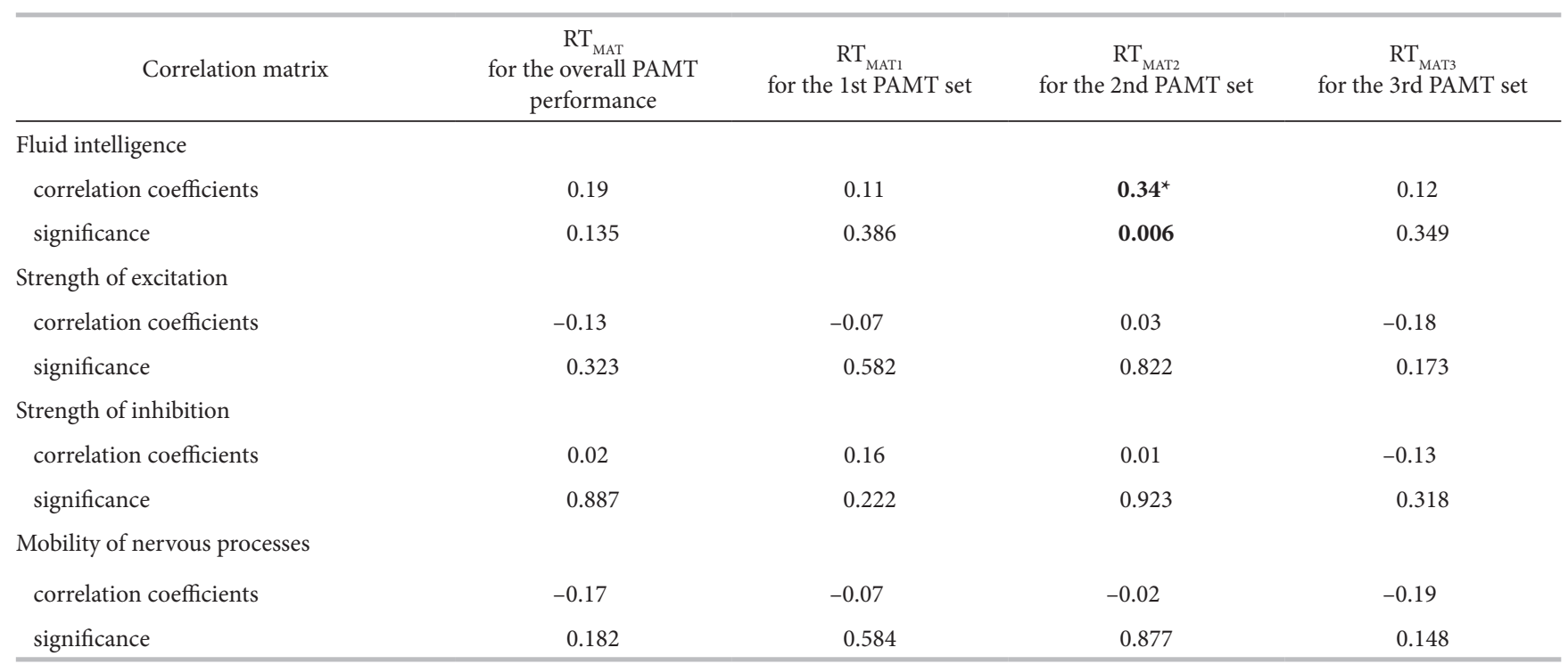

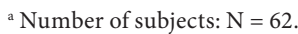

* Correlation is significant at the 0.01 level (2-tailed).

Values in bold are statistically significant.

Table 2. Regression analysis for predictors of reaction times in movement anticipation tasks (RTMAT) for the 3 PAMT task sets and the overall PAMT performance ${ }^{a}$

\begin{tabular}{|c|c|c|c|c|c|c|c|c|c|c|c|c|}
\hline \multirow{2}{*}{ Model } & \multicolumn{12}{|c|}{$\mathrm{RT}_{\mathrm{MAT}}$} \\
\hline & $\beta^{\star}$ & $\mathrm{t}$ & $\mathrm{p}$ & $\beta^{* *}$ & $\mathrm{t}$ & $\mathrm{p}$ & $\beta^{* * *}$ & $\mathrm{t}$ & $\mathrm{p}$ & $\beta^{* * * *}$ & $\mathrm{t}$ & $\mathrm{p}$ \\
\hline 1. Fluid intelligence & 0.192 & 1.514 & 0.135 & 0.112 & 0.873 & 0.386 & 0.342 & 2.821 & 0.006 & 0.121 & 0.944 & 0.349 \\
\hline 2. Fluid intelligence & 0.196 & 1.516 & 0.135 & 0.128 & 0.980 & 0.331 & 0.341 & 2.710 & 0.009 & -0.096 & -0.492 & 0.625 \\
\hline $\begin{array}{l}\text { Strength } \\
\text { of excitation }\end{array}$ & -0.045 & -0.230 & 0.819 & -0.089 & -0.450 & 0.654 & 0.022 & 0.114 & 0.909 & -0.113 & -0.881 & 0.382 \\
\hline $\begin{array}{l}\text { Strength } \\
\text { of inhibition }\end{array}$ & 0.035 & 0.271 & 0.787 & 0.170 & 1.308 & 0.196 & 0.028 & 0.228 & 0.820 & -0.110 & -0.563 & 0.576 \\
\hline $\begin{array}{l}\text { Mobility } \\
\text { of nervous } \\
\text { processes }\end{array}$ & -0.137 & -0.706 & 0.483 & -0.008 & -0.039 & 0.969 & -0.034 & -0.180 & 0.858 & -0.096 & -0.492 & 0.625 \\
\hline
\end{tabular}

a Number of subjects: $\mathrm{N}=62$.

${ }^{*} \mathrm{R}^{2}=0.068, \Delta \mathrm{R}^{2}=0.031,{ }^{* *} \mathrm{R}^{2}=0.048, \Delta \mathrm{R}^{2}=0.035,{ }^{* * *} \mathrm{R}^{2}=0.118, \Delta \mathrm{R}^{2}=0.001,{ }^{* * *} \mathrm{R}^{2}=0.067, \Delta \mathrm{R}^{2}=0.052$.

Values in bold are statistically significant.

In the second PAMT task set, the reaction time could be predicted only by the fluid intelligence scores of the examined drivers at $\mathrm{F}(1,61)=7.958, \mathrm{p}=0.006$, but not by any of their temperamental traits, at $\mathrm{F}(4,61)=1.915$, $\mathrm{p}=0.120$. A model with fluid intelligence as the only predictor explained $12 \%$ of the variance in the dependent variable $\left(R^{2}=0.12\right.$; corrected $\left.R^{2}=0.10\right)$. The value of the coefficient standardized for the general intelligence variable was $\beta=0.34, p<0.006$ (Table 2), which suggests that the higher the intelligence, the longer the reaction time in the second PAMT task set.

\section{DISCUSSION}

The present study set out to determine to what extent intelligence and temperamental traits could explain reaction times in movement anticipation tasks differing in the speed of moving objects. It was found that flu- 
id intelligence was significantly associated with reaction times only in the second PAMT task set (in which the marker moves more slowly than in the first set). In that set, fluid intelligence scores explained $12 \%$ of the variability in $\mathrm{RT}_{\mathrm{MAT}}$ Interestingly, the reaction time was found to increase with fluid intelligence. This may be attributed to a change in the level of task difficulty (a slower speed of the computer marker): individuals with higher intelligence may be more reflective and they may take more time to react under more complex test conditions, which is consistent with the findings reported by Czeschlik [21]. On the other hand, most scholars $[12,18,19,22]$ have indicated that individuals scoring higher on intelligence exhibit shorter reaction times in choice reaction tasks. However, it should be remembered that typical choice reaction tasks do not involve movement anticipation. In this study, intelligence was not a good predictor of reaction times either for the other PAMT task sets or for the overall PAMT performance. These results could be attributed to the structure of the PAMT itself. In the first set, the tasks are very simple due to the high speed of the computer marker, and so solutions do not require complex reasoning, which is in line with the study by Jensen $[11,12]$. In the third set, with the computer marker moving very slowly, successful solutions require the discovery of certain rules that were not needed in the previous tests. Rule discovery should be linked to higher levels of fluid intelligence. However, taking into consideration the overall performance, intelligence could not be used as a predictor of reaction times. This is inconsistent with the existing literature on choice reaction times [3,11-17].

The results concerning the correlations and predictive power of temperamental traits in movement anticipation tasks are not in agreement with the expectations, either. It was found that all temperamental traits were not associated with the reaction time for all tasks, and were not good predictors of these variables.

It should be noted that these results refer to reaction times without making a distinction between latency time and movement time, as the PAMT does not record these times separately. In addition, the PAMT does not measure anticipation per se, but only the speed and accuracy of reactions. Moreover, the diagnostic validity of the PAMT has still not been fully confirmed [5]. Another limitation of the present study is the fact that statistical analyses took into account only the overall fluid intelligence scores as the sample size was not sufficient to incorporate more fine-grained predictors and the participants were exclusively female. Therefore, future research should address the presented limitations and re-analyze the research problems formulated in this work. One option would be to develop a new test enabling the measurement of latency and movement times in anticipatory tasks involving objects moving at different speeds.

\section{CONCLUSIONS}

Even though the results presented by the author should be interpreted cautiously, they provide some interesting and important insights into reaction time predictors in situations where individuals are required to anticipate the motion of objects moving at different speeds.

\section{ACKNOWLEDGEMENTS}

The author would like to thank Joanna Bartnicka and Albert Andrzejewski for their assistance in organizing the research. Special thanks are also owed to all drivers participating in the study.

\section{REFERENCES}

1. Endsley MR. Towards a theory of situation awareness in dynamic systems. Hum Factors. 1995;37:32-64.

2. Terelak J. Psychologia kierowców pojazdów drogowych. Teoria i stan badań [Psychology of drivers of road vehicles. Theory and state of the art]. Warszawa: Wydawnictwo Uniwersytetu Kardynała Stefana Wyszyńskiego; 2015.

3. Truszczyński O, Różanowski K, Baran P. Wartość predykcyjna inteligencji w badaniach sprawności psychomotorycznej kierujących pojazdami [The predictive value of intelligence level in psychomotor skills tests of vehicle drivers]. Przegląd Psychol. 2012;55(4):397-410.

4. Łuczak A, Tarnowski A. Temperament i osobowość w diagnozie predyspozycji kierowców: Wyniki badań [Temperament and personality in the diagnosis of drivers' predispositions: Research results]. Warszawa: Centralny Instytut Ochrony Pracy - Państwowy Instytut Badawczy; 2013.

5. Tarnowski A. Test2Drive: Podręcznik użytkownika [Test2Drive: User’s Guide]. Siemianowice Śląskie; 2014.

6. Sommer M, Herle M, Hausler J, Risser R, Schutzhofer B, Chaloupka C. Cognitive and personality determinants of fitness to drive. Transp Res Part F. 2008;11:362-75.

7. Nęcka E. Inteligencja: geneza, struktura, funkcje [Intelligence: genesis, structure, functions]. Sopot: Gdańskie Wydawnictwo Psychologiczne; 2003.

8. Spearman C. The abilities of man. London: Macmillan; 1927. 9. Cattell RB. Abilities: Their structure, growth and action. Boston: Houghton-Mifflin; 1971. 
10. Jaworowska A, Szustrowa T. Test Matryc Ravena w wersji Standard [Raven's Test Matrix Standard]. Warszawa: Pracowania Testów Psychologicznych Polskiego Towarzystwa Psychologicznego; 2010.

11. Jensen AR. The Importance of Intraindividual in Reaction Time Variation. Pers Individ Dif. 1992;13(8):869-81.

12. Jensen AR. Spearman's hypothesis tested with chronometric information-processing tasks. Intelligence. 1993;17(1): 47-77.

13. Jensen AR, Munro E. Reaction Time, Movement Time, and Intelligence. Intelligence. 1979;3:121-6.

14. Nissan J, Liewald D, Deary IJ. Reaction time and intelligence: Comparing associations based on two response modes. Intelligence [Internet]. 2013;41(5):622-30, https:// doi.org/10.1016/j.intell.2013.08.002.

15. Schubert AL, Hagemann D, Frischkorn GT. Is general intelligence little more than the speed of higher-order processing? J Exp Psychol Gen. 2017;146(10):1498-512.

16. Schulz-Zhecheva Y, Voelkle MC, Beauducel A, Biscaldi M, Klein C. Predicting Fluid Intelligence by Components of Reaction Time Distributions from Simple Choice Reaction Time Tasks. J Intell. 2016;4(8).

17. Sheppard LD, Vernon PA. Intelligence and speed of information-processing: A review of 50 years of research. Pers Individ Dif. 2008;44(3):535-51.

18. Doebler P, Scheffler B. The relationship of choice reaction time variability and intelligence: A meta-analysis. Learn Individ Differ. 2016;52:157-66.

19. Der G, Deary IJ. The relationship between intelligence and reaction time varies with age: Results from three representative narrow-age age cohorts at 30, 50 and 69 years. Intelligence. 2017;64(March):89-97.

20. Biernacki M, Zieliński P. Inteligencja płynna a poziom koordynacji wzrokowo-ruchowej u kandydatów na pilotów [Intelligence $\mathrm{gF}$ and level of sight-motor coordination in candidates for military pilots]. Pol Przegląd Med Psychol Lot. 2011;17(3):297-304.

21. Czeschlik T. General intelligence, temperament, and the Matching Familiar Figures Test. Eur J Pers. 1993;7:379-86.

22. Deary I, Der G, Ford G. Reaction time and intelligence differences: a population based cohort study. Intelligence. 2001; 29:389-99, https://doi.org/10.1016/S0160-2896(01)00062-9.

23. Waszkowska M. Temperament a poczucie stresu w ruchu drogowym [Temperament and perceived stress in road traffic]. Med Pr. 2009;60(2):137-44.
24. Strelau J. The Concept and Status of Trait in Research on Temperament. Eur J Pers. 2001;15:311-25.

25. Strelau J. Temperament jako regulator zachowania $\mathrm{z}$ perspektywy półwiecza badań [Temperament as a regulator of behavior from the perspective of half-century research]. Gdańsk: Gdańskie Wydawnictwo Psychologiczne; 2006.

26. Strelau J, Zawadzki B. Kwestionariusz Temperamentu PTS. Podręcznik [PTS Temperament Questionnaire. Manual]. Warszawa: Pracowania Testów Psychologicznych Polskiego Towarzystwa Psychologicznego; 1998.

27. Strelau J. Temperament i typ układu nerwowego [Temperament and type of the nervous system]. Warszawa: Państwowe Wydawnictwo Naukowe; 1969.

28. Daum I, Hehl FJ, Schugens MM. Construct validity and personality correlates of Strelau Temperament Inventory. Eur J Pers. 1988;2:205-16.

29. Pascalis V De, Strelau J, Zawadzki B. The effect of temperamental traits on event-related potentials, heart rate and reaction time. Pers Individ Dif. 1999;26:441-65, https:// doi.org/10.1016/S0160-2896(01)00062-9.

30. Miklewska A, Kaczmarek M, Strelau J. The relationship between temperament and intelligence: Cross-sectional study in successive age groups. Pers Individ Dif. 2006;40(4): 643-54.

31. Miklewska A. Temperament a inteligencja - przegląd badań [Temperament and intelligence - state of the art]. Pr Nauk Wyższej Szk Pedagog w Częstochowie. 2003;10: 91-104.

32. Strelau J, Zawadzki B, Piotrowska A. Modele temperamentu nawiązujące do teorii aktywacji i ich implikacje dla inteligencji [Models of temperament referring to the theory of activation and their implications for intelligence]. Stud Psychol. 1997;35:165-201.

33. Komenda Główna Policji. Wypadki drogowe w Polsce w 2016 roku [Traffic accidents in Poland in 2016]. Warszawa; 2017.

34. Field A. Discovering statistics using IBM SPSS Statistics. Los Angeles-London-New Delhi-Singapore-Washington DC: Sage Publications, Inc.; 2013.

35. Grubbs FE. Sample Criteria for Testing Outlying Observations. Ann Math Stat. 1950;21(1):27-58.

36. Ratcliff R. Methods for Dealing with Reaction-Time Outliers. Psychol Bull. 1993;114(3):510-32.

This work is available in Open Access model and licensed under a Creative Commons Attribution-NonCommercial 3.0 Poland License - http://creativecommons.org/licenses/by-nc/3.0/pl/deed.en. 